DOI: $10.2478 / \mathrm{v} 10235-011-0004-3$

\title{
Ljiljana Progovac
}

\section{Compounds and commands in the evolution of human language*}

\begin{abstract}
It is in the personal nicknames that we must look for the more unceremonial every-day speech of our ancestors.
\end{abstract}

(Weekley 1927: 159)

\section{Introduction}

Jackendoff $(1999,2002)$ has proposed that the evolution of syntax might have preserved "fossils" of previous stages in its later stages (see also Bickerton 1990), mentioning compounds (e.g. snowman) as one such living fossil. ${ }^{1}$ I argue in this paper that a special kind of compound, exocentric VN compound, constitutes the most plausible candidate for a syntactic fossil. Not only is the grammar of compounds in general considered to be a protosyntactic fossil, but the imperative mood is also taken to be a protolinguistic form (Rolfe 1996). Since VN compounds feature an imperative verb, as will be shown,

* For generous travel support, I am grateful for the WSU Distinguished Faculty Award and the Humanities Grant for Innovative Projects. Native speakers of various languages have offered me invaluable examples of $\mathrm{VN}$ compounds, only some of which I was able to quote and acknowledge in the relevant sections of this paper. In addition to these, I am also grateful for many good comments and discussions, especially to Martha Ratliff, Eugenia Casielles, Paweł Rutkowski, John Locke, Ana Progovac, Natasha Kondrashova, Relja Vulanović, as well as (other) audiences at 2006 SLS, 2006 and 2007 MLS, 2007 Max Planck Workshop on Complexity, Leipzig, 2007 and 2008 FASL, 2007 AATSEEL, 2008 BALE, York, England, 2008 NSGSW, Novi Sad, Serbia, and especially 2009 Ways to Protolanguage conference, Torun, Poland. All errors are mine.

According to Ridley (1993, 525), living fossils are species that have changed little from their fossil ancestors in the distant past, such as e.g. lungfish. 
they are doubly significant for protosyntax. In fact, both the rudimentary morphosyntactic make-up of these compounds and their (derogatory) semantics are consistent with an evolutionary approach.

It is typically reported in linguistics literature (whether monographs or textbooks) that verb-noun (VN) compounds of the kind illustrated in (1) are exceptional in that they are exocentric (i.e. not headed), in contrast to the compounds illustrated in (2), which are headed by the second/rightmost element in the compound (e.g. Spencer 1991, Selkirk 1982):

(1) pickpocket, scarecrow, turncoat, daredevil, hunchback, wagtail, tattletale, sawbones

(2) toothbrush, headboard, bedroom, blackboard, navy-blue

While a toothbrush is a kind of brush, and navy-blue is a kind of blue, a scarecrow is neither a kind of crow nor a kind of scare. It is rather a person or a thing that scares crows. This is puzzling given that all morpho-syntactic structure is considered to be headed, headedness and hierarchy constituting the hallmarks of modern syntactic theory (e.g. Chomsky's (1995) Minimalism and predecessors). Williams' (1981) Righthand Headedness Rule thus seems applicable in describing the headed compounds in (2), but not the exocentric (headless) compounds in (1). This is only one of many ways in which VN compounds are surprising.

Another unexpected detail is that the verb in VN compounds surfaces in the imperative form, which is clearly observable in Serbian compounds (next section), but has also been proposed for VN compounds in other languages, including Slavic and Romance (Section "Surprising scope and cross-linguistic parallels"). As will be shown, VN compounds are found across languages, not only Indo-European (IE), but also non-IE, exhibiting striking parallelisms in form and imagery.

Consistent with the evolutionary approach, VN compounds feature very basic vocabulary, frequently denoting body parts and functions. They in fact specialize for derogatory reference, and are often coarse and vulgar. The majority of these compounds has been preserved in names and nicknames, suggesting that their primary use was for naming/nicknaming purposes. Formation of thousands of these compounds, many of which are expressive, humorous and playful, may point to ritual insult, which rewarded creativity and coarse humor, possibly contributing to sexual selection of basic proto-syntax (Progovac \& Locke 2009) (Section "Sexual selection and the representation in the brain"). 
Structurally speaking, VN compounds can be analyzed as simple (nonhierarchical) combinations/concatenations of exactly two words, a verb and a noun, which can be seen as the verb's only argument. The thematic (theta) role of the noun, even though typically theme, can in fact be demonstrated to be largely underdetermined, even vague. Once this is realized, many more compounds can be shown to belong to this type than is typically assumed (e.g. rattlesnake, crybaby) (Section "Evolutionary claim...)".

Some corroborating evidence for the proposal comes from language acquisition studies (Section "Acquisition") and language representation in the brain (Section "Sexual selection"). To the extent that they can best be understood in the evolutionary framework, these compounds constitute an argument for the gradualist approach to the evolution of syntax, in the spirit of e.g. Pinker \& Bloom (1990), Jackendoff (1999, 2002), Progovac (2008) and references cited there.

\section{Surprising form: Imperative}

Sanskrit 'imperative' comprises more than is conveyed by its European name. It is not only the equivalent of what we are wont to understand by this mood, but it is also expressive of wishes, benedictions, possibility, and doubt ... (Speijer 1886: 271-273)

Linguists/grammarians converge on the conclusion that $\mathrm{VN}$ compounds in Serbian consist of an imperative verb plus a noun (Stevanović 1956, Mihajlović 1992, Maretić 1899, Belić 1949, Živanović 1904, Progovac 2005, 2006). Imperative in Serbian has a characteristic $i / j$ ending. Although there is an overlap with some verbs, those verbs which have distinct forms for the base 3SG (third person singular) present and for the imperative unmistakably show that it is the imperative form which is used in these compounds, as marked in the table below:

(3) VN compounds as common nouns in Serbian

\begin{tabular}{lll}
\hline cepi-dlaka & [split-hair = hairsplitter] & IMP \\
deri-koža & [rip-skin = person who rips you off $]$ & IMP \\
ispi-čutura & [empty-flask = drunkard] & IMP/3SG \\
jebi-vetar & [screw-wind = charlatan] & IMP \\
jedi-vek & [eat-life = one who constantly annoys $]$ & IMP \\
kljuj-drvo & [archaic: peck-wood = wood-pecker $]$ & IMP \\
liz-guz & [lick-butt] & IMP/3SG \\
liži-sahan & [dialectal: lick-basin = boot-licker $]$ & IMP
\end{tabular}




\begin{tabular}{|c|c|c|}
\hline kosi-noga & [skew-leg $=$ lame person $]$ & IMP \\
\hline muti-voda & [muddy-water $=$ one who muddies waters] & $\mathrm{IMP} / 3 \mathrm{SG}$ \\
\hline pali-drvce & [burn-stick $=$ matches $]$ & $\mathrm{IMP} / 3 \mathrm{SG}$ \\
\hline pali-kuća & [burn-house $=$ one who burns houses] & $\mathrm{IMP} / 3 \mathrm{SG}$ \\
\hline podvi-rep & [fold-tail $=$ someone who is crestfallen] & IMP \\
\hline poj-kurić & [sing-penis = womanizer] & $\mathrm{IMP} / 3 \mathrm{SG}$ \\
\hline priši-petlja & [sow-loop $=$ who clings onto another] & IMP \\
\hline probi-svet & [break-world = wanderer $]$ & IMP \\
\hline raspi-kuća & [waste-house $=$ who spends away property] & IMP \\
\hline razbi-briga & [break-worry $=$ game/entertainment $]$ & IMP \\
\hline seci-kesa & [cut-purse $=$ pick-pocket $]$ & IMP \\
\hline vadi-čep & [takeout-cork $=$ corkscrew $]$ & $\mathrm{IMP} / 3 \mathrm{SG}$ \\
\hline$v r t i-g u z$ & [spin-butt $=$ restless person, fidget $]$ & IMP/3SG \\
\hline vrti-rep & [wag-tail $=$ restless person, fidget $]$ & IMP/3SG \\
\hline vuci-batina & [pull-whip = tramp, good-for-nothing] & IMP \\
\hline
\end{tabular}

Notice that almost all the compounds referring to humans are derogatory. This compounding strategy has also been used in more recent times for official naming purposes, in which case the results are not derogatory, but in fact tend to express grand wishes:

(4) VN compounds as names in Serbian

"Names in Slavonic are for the most part grand and poetical compounds."

\begin{tabular}{|c|c|c|}
\hline Bodi-roga & [pierce-horn?] & IMP \\
\hline Bori-voj & [fight-war] & $\mathrm{IMP} / 3 \mathrm{SG}$ \\
\hline Brani-mir & [defend-world?] & $\mathrm{IMP} / 3 \mathrm{SG}$ \\
\hline Budi-mir & [be-world?] & IMP \\
\hline Budi-sava & [be-?] (town) & IMP \\
\hline Deli-blato & [divide-mud] (town) & $\mathrm{IMP} / 3 \mathrm{SG}$ \\
\hline Jezdi-mir & [ride-world] & $\mathrm{IMP} / 3 \mathrm{SG}$ \\
\hline Kolji-vratić & [cut-throat] & IMP \\
\hline Kruni-slav & [crown-glory] & $\mathrm{IMP} / 3 \mathrm{SG}$ \\
\hline Popi-voda & [drink-water] & IMP \\
\hline Rasti-slav & [grow-glory] & $\mathrm{IMP} / 3 \mathrm{SG}$ \\
\hline Stani-mir & [stay-world] & IMP \\
\hline Stani-slav & [stay-glory] & IMP \\
\hline Sveti-mir & [bless-world] & $\mathrm{IMP} / 3 \mathrm{SG}$ \\
\hline Trpi-mir & [endure-world] & $\mathrm{IMP} / 3 \mathrm{SG}$ \\
\hline Strati-mir & [waste-world] & $\mathrm{IMP} / 3 \mathrm{SG}$ \\
\hline Veli-mir & [command world] & $\mathrm{IMP} / 3 \mathrm{SG}$ \\
\hline Vladi-mir & [rule-world] & $\mathrm{IMP} / 3 \mathrm{SG}$ \\
\hline Zlati-bor & [gild-pine] (mountain) & $\mathrm{IMP} / 3 \mathrm{SG}$ \\
\hline Zlati-slav & [gild-glory] & $\mathrm{IMP} / 3 \mathrm{SG}$ \\
\hline
\end{tabular}


It has been proposed that naming was among the first uses of language for referential purposes, preceding the so-called epistemic stage, expressing propositions or statements (e.g. Rolfe 1996). Rolfe also hypothesizes that humans initially used verbs to issue commands (imperative), even in the oneword (pre-syntactic stage), and much before using verbs to make statements. Imperative in general is among the first productive verbal forms used by children (e.g. Bar-Shalom \& Snyder 1999), and it tends to be the least marked verbal form across languages, and/or to preserve archaic patterns (e.g. Dixon 1994: 189; Kurylowicz 1964: 137). Imperatives arguably also provide some continuity with animal calls in the sense that they are calls for action. If $\mathrm{VN}$ compounds emerged at an early stage of protosyntax, then it is plausible that they would have been tinkered from what was already there - the imperative verbal form. But it is important to keep in mind that one is dealing here with a proto-imperative form, not with what is meant by imperative in present-day languages. This proto-imperative would have had a much wider range of functions than modern imperative has today (in this respect, the quote by Speijer (1886) under the section title, regarding the imperative form in Sanskrit, is suggestive).

In fact, this proto-imperative form is used in Serbian in other functions as well, clearly functions that would not sanction the use of what is today considered as imperative. For example, some petrified optative/subjunctive forms such as English (5) are rendered in Serbian using the imperative form again (6):

Long Live the King! God Forbid!

$\begin{array}{lll}\text { a. } & \text { Pomozi } & \text { Bog! } \\ & \text { Help.IMP } & \text { God } \\ \text { b. } & \text { Hvali } & \text { Bog! } \\ & \text { Praise.IMP } & \text { God }\end{array}$

Another example comes from the archaic Historical Imperative, which used to be productive in narratives, but is now only used in some dialects of Serbian (Stevanović 1966: 412-413):

(7) A on ti skini motiku s ramena, zabiije u zemlju, ostavi fenjer kraj sebe i sedi na ladju.

"And he take off-IMP the spade from his shoulder, stick-IMP it into the ground, leave-IMP the lantern by himself, and sit-IMP onto the boat."

2 In fact, there is a name in Polish that has exactly the same make-up (example 8). 
It is perhaps relevant for these considerations that Slavic imperative descended from the optative mood (e. g. Belić 1960; Kerns \& Schwartz 1972: 23), expressing wishes, which are often indistinguishable from commands. For more connections between various proto-IE moods and the imperative in Serbian compounds, see Progovac $(2006,2010)$.

\section{Surprising scope and cross-linguistic parallels}

VN compounds are found in a wide range of languages, including non-IE, showing striking parallels in form and imagery, as illustrated in this section.

\section{VN compounds in other Slavic languages}

In addition to Serbian, the imperative analysis for $\mathrm{VN}$ compounds has also been proposed for Bulgarian (Andreǐčin 1955) and Macedonian (e.g. Koneski 1954). For Polish, it is sometimes claimed that $-i$ is a connecting vowel (e.g. Ułaszyn 1923). Polish lost the imperative in $-i$ by the end of the $16^{\text {th }}$ century, and Mirowicz (1946) advocates a diachronic imperative analysis of VN compounds in Polish. According to Klemensiewicz et al. (1964: 256257), VN compounds in Polish went through several stages, including an imperative stage. The following are some examples from Polish and Russian.

(8) $\quad$ Polish (supplied and/or glossed by Paweł Rutkowski, p.c.)

$\begin{array}{ll}\text { Chwali-bóg } & \text { [praise-god] } \\ \text { dusi-grosz } & \text { [squeeze-penny, niggard] } \\ \text { goli-broda } & \text { [shave-beard, barber] } \\ \text { hulaj-dusza } & \text { [roister-soul, reveler, rioter] } \\ \text { Kopaj-gród } & \text { [dig-town] (place name) } \\ \text { tami-strajk } & \text { [break-strike, strike-breaker] } \\ \text { tami-główka } & \text { [break-head:DIM, puzzle, riddle] } \\ \text { maci-woda } & \text { [muddy-water, troublemaker, brawler] } \\ \text { moczy-morda } & \text { [soak-muzzle, sot, drunkard] } \\ \text { obieży-świat } & \text { [trot-world, globe-trotter] } \\ \text { pali-woda } & \text { [burn-water, flibbertigibbet, madcap] } \\ \text { pasi-brzuch } & \text { [pasture-belly, glutton, lazybones] } \\ \text { pędzi-wiatr } & \text { [drive-wind, flibbertigibbet, madcap] } \\ \text { rzezi-mieszek } & \text { [cut-purse, pickpocket] } \\ \text { wali-góra } & \text { [topple-mountain, giant of Polish folklore who could } \\ & \text { topple mountains] } \\ \text { wierci-pięta } & \text { [wiggle-heel, fidget] } \\ \text { wozi-woda } & \text { [carry-water, water-carrier] }\end{array}$


(9) Russian (Yana Pugach, Maria Babyonyshev, Dina Brun, Asya Pereltsvaig, p.c.)

lomi-golovka [break-head, brain-teaser/puzzle]

sorvi-golova [cut-off head, daredevil]

perekati-pole [roll-over-field, tumbleweed]

verti-hvostka [wag-tail, a bird]

\section{VN compounds in English}

"These formations... often seem to originate in an ironical imperative" (Jespersen 1954: 224)

Just like in Serbian and other Slavic languages, English VN compounds pertaining to humans also tend to be derogatory, unless they are more recently coined names:

(10) scare-crow, kill-joy, pick-pocket, cut-purse, spoil-sport, turn-coat, hunchback, dare-devil, wag-tail, tattle-tale, saw-bones, cut-throat, Shake-speare, Burn-house, Drink-water, Bere-water, Love-joy, Drynk-pany (miser), Pinch-penny (miser)

For many more examples in English, the reader is referred to e.g. Weekley (1916), Jespersen (1954: 223-224; 347-350), Marchand (1969: 380-382), Adams (1973). According to Weekley (1916), in medieval times these compounds showed "unquotable coarseness," but were nonetheless a very expressive way of naming, found plentifully in all the related European names; they swarm in $13^{\text {th }}$ and $14^{\text {th }}$ century. Most reference books have eliminated them, driving them to virtual extinction, not only in English, but in other languages as well (see also Lloyd 1968, Darmesteter 1934, Mihajlović 1992).

\section{VN compounds in Romance languages}

At the time of Renaissance, Ronsard introduced [VN compounds] in a new and original manner as epithets: Jupiter lance-tonnerre, le soleil donne-vie, Hercule porte-massue... It would be well could French poets again make use in lofty poetry of this class of epithets; for they may attain Homeric breadth... (Darmesteter 1934: 443).

Here are some examples from Spanish and Italian (some French data can be found in (15) below). 
(11) Spanish (Eugenia Casielles, p.c.)

$\begin{array}{lc}\text { rompe-cabezas } & \text { [break-heads, puzzle] } \\ \text { saca-muelas } & \text { [extract-teeth, hack dentist] } \\ \text { lame-culos } & \text { [lick-asses] } \\ \text { calienta-pollas } & \text { [heat-penises, a tease] } \\ \text { Italian (Hall 1948, } 175-176 ; \text { Murray 2004) } \\ \text { akkatta-pane } & \text { [beg-bread, beggar] } \\ \text { metti-male } & \text { [put-evil, trouble-maker] }\end{array}$

According to Lloyd (1968), Romance VN compounds originated from nicknames, usually playful and humorous, and then spread to other areas around $12^{\text {th }} / 13^{\text {th }}$ century, such as places, instruments, occupations, plants. ${ }^{3}$ Many of the original VN compounds are reported to have been used by the lowest classes of society, and to have been coarse and humorous. The imperative analysis for such Romance compounds was proposed by many, e.g. Diez (1838), Darmesteter (1894, 1934), Prati (1931), Lloyd (1968). Most historical grammars followed Darmesteter's imperative analysis (e.g. Meyer-Lübke (1895: 213-214) and Rohlfs (1954)), while some assumed the 3 person singular form of the verb (e.g. Bolufer 1920: 170).

\section{VN compounds in non-Indo-European languages}

VN compounds with comparable morphological make-up can also be found in non-IE languages, such as Tashelhit Berber and Chinese:

$\begin{array}{ll}\text { Tashelhit Berber } & \text { (Dris Soulaimani, p.c.) } \\ \text { slm-aggrn } & \text { [suck.in-flour, butterfly] } \\ \text { ssum-sitan } & \text { [suck-cow, insect] } \\ \text { ssum-izi } & \text { [suck-fly, thrifty person] } \\ \text { Chinese (Murray } & \text { 2004; Haiyong Liu, p.c.) } \\ \text { dean-shin } & \text { [stay-stomach, refreshments] } \\ \text { liing-shyh } & \text { [lead-affairs, consul] } \\ \text { ua-eel } & \text { [dig-ear, ear-pick] }\end{array}$

3 It may be that in these more recent creations in Romance languages, VN compounds have re-emerged in a slightly more complex syntactic form than original VN compounds, judging not only by their productiveness (mostly in non-human uses), but also by the frequent use of plural nouns inside these compounds (e.g. Murray 2004, Ferrari 2005). See Footnote 7 for additional discussion of this issue. 


\section{Crosslinguistic Parallelisms}

VN compounds are found across various languages with striking similarity in morphological make-up and metaphorical expression, as the following table helps illustrate:

\begin{tabular}{|c|c|c|c|c|}
\hline English & Serbian & French & Polish & Spanish \\
\hline $\begin{array}{l}\text { Drink-water } \\
\text { cut-purse } \\
\text { cut-throat } \\
\text { lick-pot }\end{array}$ & $\begin{array}{l}\text { Popi-voda } \\
\text { seci-kesa } \\
\text { Koji-vratić } \\
\text { liži-sahan }\end{array}$ & $\begin{array}{l}\text { Boileau } \\
\text { coupe-bourse } \\
\text { coupe-gorge }\end{array}$ & rzezi-mieszek & 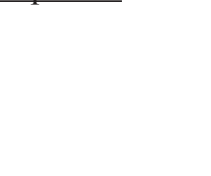 \\
\hline Bere-water & & & $\begin{array}{l}\text { tami-główka } \\
\text { wozi-woda }\end{array}$ & ompe-cabezas \\
\hline $\begin{array}{l}\text { Burn-house } \\
\text { wag-tail } \\
\text { pinch-penny }\end{array}$ & $\begin{array}{l}\text { pali-kuća } \\
\text { vrti-rep }\end{array}$ & grippe-sou & dusi-grosz & \\
\hline
\end{tabular}

Notice in this respect that Tashelhit ssum-sitan [suck-cow] in (13) is closely parallel to Old English burst-cow, which also meant "insect," and the drinking image for a miser drynk-pany (10) is reminiscent of ssum-izi [suckfly] in Tashelhit Berber (13).

According to Lloyd (1968), the original VN compounds described people who were lazy, useless, careless in dress, idle, contemptible, criminal, stupid, uncultured, bullies, busybodies, flatterers, gluttons, drunkards, gloomy, cheating and swindling, misers, defective, of contemptuous professions. If these descriptive words were not available to ancient humans, which is a reasonable assumption to make, then the VN naming strategy would have increased their expressive power (as well as the insulting power) enormously. In other words, the ability to use such compounding strategy successfully would have constituted an enormous expressive advantage over just using single-word utterances, an advantage which could have been subject to sexual selection.

\section{Evolutionary claim: VN compounds as "fossils" of a proto-syntactic stage}

The grammar behind VN compounds, including the (imperative) mood morphology, begins to make sense only if seen as a fossil of the very beginnings of syntax. I argue that VN compounds, at least in English and 
Serbian, are flat (non-hierarchical) concatenations of exactly two words, a verb and a noun (Proto-Merge), where the noun is the verb's only argument (see Jackendoff $(1999,2002)$ for the claim that adjunction/parataxis is a protosyntactic fossil). The thematic role of the noun, although typically theme, is in fact largely underdetermined (proto-theta-role). While the noun is interpreted as an argument of the verb, it is not structurally specified whether this argument is agent or theme, pointing to the rather rudimentary verb-argument semantics, as explored in this section. ${ }^{4}$

\section{Proto-predication}

The noun in VN compounds is not always the object or the theme of the verb, as is typically assumed in the literature. While the examples in (16a) are unaccusatives, whose nouns can be analyzed as themes, those in (16b) involve an agent. The compound strategy, however, is identical in both cases, complete with the imperative morphology:

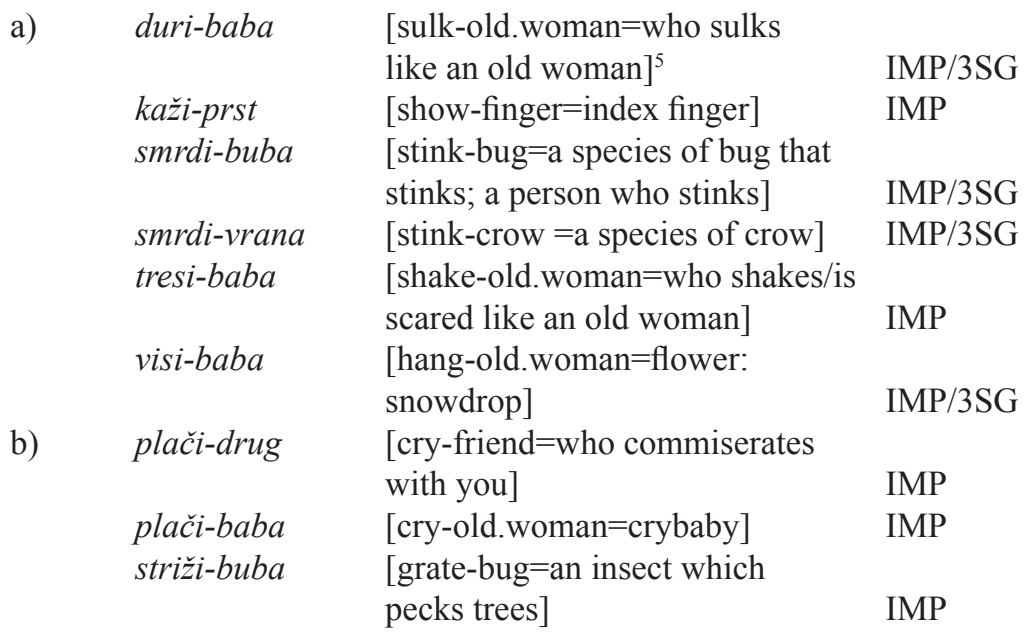

4 In the spirit of Downing (1977), Gil (2005) suggests that root compounds (e.g. toothbrush, snowman), as well as some other constructions in various languages, involve an association operator semantically. The semantics of VN compounds involves (a bit) more than just association, a participant in the event, and thus a relationship which can be termed "(proto-) predication."

5 As pointed out in Mihajlović (1992), baba is a complex piece to translate since it involves layers of meaning, including "woman," "old woman" and "witch." In fact, many of these compounds are impossible to translate accurately, given that they preserve older uses and meanings of morphemes, no longer accessible. 


$\begin{array}{lll}\text { tuži-baba } & \text { [complain-old.woman=who } & \\ \text { trči-laža } & \text { complains like a woman] } & \text { IMP/3SG } \\ & \text { [run-lie=one who spreads lies }] & \text { IMP/3SG }\end{array}$

There is no reason to treat (16b) distinctly from (16a) or (3) above, given their identical morphological make-up, as well as (derogatory) semantics. The following English examples are considered to be distinct from exocentric compounds because they seemingly have a head:

rattle-snake, catch-word, cry-baby, stink-bug, worry-wart, copy-cat, scapegoat

Notice, however, the similarity between English rattle-snake (17) and Serbian tresi-baba (16a); English worry-wart (17) and Serbian duri-baba (16a). My conclusion is that the compounds in (16) and (17), together with those in $(1 \& 3)$, are all instances of the same exocentric VN strategy, where the noun's typical theta role is theme, but where agentive interpretations are not structurally excluded, attesting to a proto-predication character of the compounding process. The following two subsections provide support for this conclusion.

\section{Ambivalence in semantic headedness}

The most expressive of VN compounds can in fact be doubly-interpreted, allowing the noun to play the role of the agent and theme at the same time, providing a strong argument for the proto-semantic character of these compounds. For example, English dare-devil is the one who dares the devil, and can also be the one who is a devil himself. In Serbian pali-drvce [ignitestick, matches], drvce is both a theme and an agent (the stick is both ignited and igniting). Since both interpretations are available at the same time, the assignment of theta roles here has to be a matter of vagueness, rather than ambiguity (Progovac \& Locke 2009). The vagueness is typically associated with paucity of structure, while the ambiguity is typically ascribed to distinct structural possibilities (see e.g. Kempson (1977) for the distinction).

\section{Ambivalence in morphological headedness}

This subsection provides another argument for the rudimentary nature of $\mathrm{VN}$ compounds. In some sense, the noun in Serbian compounds acts as a morphological head of the whole compound, but in another sense, it does not, as illustrated in the following table: 
(18)

\begin{tabular}{llll} 
Nominative & & Accusative & \\
\hline ta.F. /taj.M.(this) & trči-laža.F & tu.F/tog.M & trči-laž-u.F \\
ta/taj & ispi-čutura.F & tog/tu & ispi-čutur-u.F \\
taj & jebi-vetar.M & tog & jebi-vetr-a.M.Animate \\
taj & vadi-čep.M & taj & vadi-čep.M.Inanimate \\
to.N & pali-drvce. $\mathrm{N}$ & to. $\mathrm{N}$ & pali-drvce. $\mathrm{N}$
\end{tabular}

For the F noun čutura [flask], the compound is declined as a simple F noun would be, as demonstrated by the characteristic $\mathrm{F}$ accusative ending $-u$ (čuturu). The choice of the demonstrative is also influenced, although not determined, by the $\mathrm{F}$ form of the noun: if the noun is $\mathrm{F}$, the demonstrative for the whole compound can be either F or M, the latter probably available by default (see Ferrari (2005) for an important role played by default M gender in compounds and word formation in general). ${ }^{6}$ The latter possibility suggests that the noun in a VN compound is not really or exhaustively its morphological head. Unlike with the other morpho-semantic gender mismatches in Serbian, the F demonstrative can be freely used with VN compounds to refer to males, suggesting an ambivalence in gender choice not attested elsewhere in the grammar.

If the noun is inanimate $\mathrm{M}$ (vetar [wind]), and the compound human/ animate, the demonstrative must be $\mathrm{M}$ as well, but the whole compound in the accusative form would follow an animate accusative pattern, with an ending in $-a$ (jebi-vetr-a). On the other hand, if the compound as a whole refers to an instrument/inanimate object, and if, moreover, its noun is inanimate and $\mathrm{M}$ ( $\check{e}$ ep [cork]), then the demonstrative must be $\mathrm{M}$, and the whole compound also follows the accusative inanimate $\mathrm{M}$ pattern. When the noun is inanimate $\mathrm{N}$ (drvce [stick]), and the whole compound is also inanimate, the demonstrative must be $\mathrm{N}$ as well, and the accusative follows the inanimate pattern.

\section{Structure of VN compounds in comparison to their productive (headed) counterparts}

Recall that the proposed analysis of exocentric compounds involves a flat concatenation of the verb and its only argument, a noun, making use of a single instance of the principle of (Proto)-Merge. This Proto-Merge,

6 On the other hand, Ferrari (2005) reports that Italian VN compounds are uniformly $\mathrm{M}$, suggesting that they may have more morpho-syntactic structure, including a null M suffix (see also Footnote 3). For a null suffix analysis of French VN compounds, see e.g. Rohrer (1977) and Lieber (1992). 
with its non-hierarchical, flat structure, arguably coincides with rudimentary predicate-argument semantics, proto-predication. From an evolutionary perspective, this structure and thematic organization can be seen as a precursor/foundation for the hierarchical structure of (more elaborate) clauses (e.g. Progovac 2008), as well as of more elaborate verbal compounds. Consider the following verbal (synthetic) compounds in English and Serbian, also composed of a verb and a noun, but involving additional moprhology:

(19) truck-driver, meat-eater, brick-layer, story-teller, tax-payer, heart-breaker

(20) a. kamen-o-rez-ac [stone-AGR-carve-AGENT stone-carver]

b. srebr-o-ljub-ac [silver-AGR-love-AGENT who admires money]

c. žen-o-mrz-ac [woman-AGR-hate-AGENT

d. ver-o-lom-ac [faith-o-break-AGENT who converts]

e. brak-o-lom-ac [marriage-AGR-break-AGENT who breaks

f. rib-o-lov-ac [fish-AGR-hunt-AGENT fisherman]

The two compound types are comparable given that both utilize the same free morphemes, a verb and a noun, to express similar concepts:
a. der-i-koža
$k o \check{z}-o-d e r-a c$
[rip-IMP-skin
[skin-AGR-rip-AGENT
b. liž-i-sahan
[lick-IMP-basin
čank-o-liz-ac ${ }^{7}$
[basin-AGR-lick-AGENT
who rips you off]
who rips you off]
boot-licker]
boot-licker]

(22) kill-joy vs. joy-killer; Bere-water vs. water-bearer/carrier

The compounds in (19-20) not only have more morphological pieces, but they also show an obligatory rearrangement of the two free morphemes, the verb and the noun. VN compounds can be taken to reflect the underlying word order (e.g. Lieber 1992; Murray 2004). According to Progovac (2005), -ac/-er compounds have an additional layer of structure, the transitivity layer. Here, the agentive morpheme -ac/-er would be generated in the vP layer, the way agents are in the Minimalist approach (see also Roeper 1999b). This structure necessitates Move of the internal argument and its incorporation

7 The two compounds in (21b), coming from two different dialects, clearly illustrate the distinction in the use of the verb form: imperative in the VN compound (liži in both dialects), and the root form in endocentric compounds (liz in both dialects). 
into the verb (e.g. Baker 1988; see also Lees 1960, Roeper \& Siegel 1978, Lieber 1992). ${ }^{8}$

$$
[\text { der }-k o \check{a} a] \rightarrow[\mathrm{VP}-a c[\text { der-koža }] \rightarrow[\text { kož-o-der-ac }]
$$

The added precision in theta-role assignment in -ac/-er compounds arguably comes from the additional layer of structure, the transitivity layer: the introduction of the external argument necessitates that the lower argument (internal argument) be a non-agent:

cry-baby vs. *baby-crier; show-finger (=index-finger) vs. finger-shower; rattle-snake vs. snake-rattler

This is reminiscent of the behavior of some ergative verbs when used without a specifically marked agent, as shown in the following example from Tongan (Tchekhoff 1979, 409):

'oku kai 'ae iká.
PRES eat the fish
"The fish eats. / The fish is eaten."

Once a specifically marked agent is introduced (e.g. the man), its very presence renders the fish the semantic patient/theme. The addition of the agent morpheme (-er/-ac) in compounds has a comparable effect. While a rattlesnake in principle can be interpreted either as a snake that rattles or as a rattler of snakes, snake-rattler can only have the latter interpretation. The grammar of $\mathrm{VN}$ compounds thus resembles the grammar of ergative intransitive verbs where only one argument is present.

Even though one compound type can be shown to be more complex than the other, it is significant for the evolutionary argument that there is continuity of structure between the two compound types.

\section{Acquisition}

Another reason to consider exocentric VN compounds as derivationally related to their endocentric counterparts comes from language acquisition

8 For postulating VP in nominalizations, see e.g. Lees (1960), Lieber (1992), Fu, Roeper \& Borer (2001); for movement/incorporation in word formation, see e.g. Fabb (1984). 
data, as pointed out in e.g. Lieber (1992). Clark, Hecht \& Mulford (1986) report that there is a stage in L1 acquisition in which children consistently produce compounds such as grate-cheese instead of cheese-grater, rippaper instead of paper-ripper. According to them, children begin to form compounds with VN predicate order, from VPs, relying initially on sentential order of elements. It is only later that they begin to move the complement/ object. ${ }^{9}$ In addition, imperative in general is among the first productive verbal forms used by young children (Bar-Shalom \& Snyder 1999). It is conceivable that imperative is a paradigm case of an unmarked mood form, and that for that reason it emerges early, whether in evolution or acquisition. The acquisition data are thus consistent with the view that the grammar behind VN compounds represents an evolutionary fossil. ${ }^{10}$

\section{Sexual selection and the representation in the brain}

VN compounds, across languages and cultures, are typically playful, pejorative, and/or vulgar.

Their expressive potential seems unmatched by any other (nick) naming strategy. For example, Serbian pijanica [drunkard] is not nearly as expressive (insulting, humorous and witty at the same time) as the VN compound ispičutura [empty-flask]. The same is true of the contrast in English between e.g. a daring person vs. dare-devil). According to Darmesteter (1934: 443), the artistic beauty and richness of these compounds (in French) is inexhaustible. Mihajlović (1992), who devoted his career to collecting over 500 Serbian place and people names in the form of $\mathrm{VN}$ compounds, reports that these condensed compositions pack in them not only sentences, but also frozen fairy tales, proverbs, and ancient wisdoms and metaphors (1992: 8-9).

According to Progovac \& Locke (2009), formation and use of VN compounds may have been an adaptive way to compete for status and sex in ancient times. Their successful use would have enhanced relative status

9 Miller (1975) argues that there is something natural/primary about verb initial word order, and that this is also confirmed in acquisition. According to him, the oldest reconstructible stage of IE may have been VSO, and Amharic and the other modern Semitic languages of Ethiopia, which are all SOV, descended from VSO parent.

10 According to e.g. Studdert-Kennedy (1991), Rolfe (1996) and Locke (2009), present-day views of ontogeny/ phylogeny warrant the use of ontogeny (development in children) to corroborate hypotheses about phylogeny (development in species). 
first by derogating existing rivals and placing prospective rivals on notice; and second by demonstrating verbal skills and quick wittedness. Darwin (1874) identified two distinct kinds of sexual selection: aggressive rivalry and mate choice (see also Miller 2000), both of which seem relevant for the proposed use of exocentric compounds. Darwin (1872) also pointed out that strong emotions expressed in animals are those of lust and hostility, and they may have been the first verbal threats and intimidations uttered by humans (Code 2005: 322).

Throughout recorded history, sexually mature males have issued humorous insults in public (Locke 2009, Locke \& Bogin 2006). These "verbal duels" are taken to discharge aggressive dispositions, and provide a way to compete for status and mating opportunities without risking physical altercations (Marsh 1978, Parks 1990). In this respect it is significant that the vulgar VN compounds e.g. in Serbian typically target males (e.g. jebi-vetar [screw-wind, charlatan]; even those that describe females are typically used in reference to males, for a doubly insulting effect (Mihajlović, 1992): laj$k u c ̌ k a$ [bark-bitch, loud and obnoxious person]; lezi-baba [lie-(old.)woman, loose woman or man].

The vast number of these compounds (reported to have been in the thousands) clearly exceeds what is needed for survival or just communication. Such excess is typically ascribed to sexual selection forces. According to Miller (2000: 369): "if language evolved in part through sexual choice as an ornament or indicator, it should be costly, excessive, luxuriant beyond the demands."

It has been reported that swear words in general, including some which are frequently found in vulgar $\mathrm{VN}$ compounds, are processed by the more ancient structures of the brain, suggesting that they themselves might be ancient creations. According to e.g. Code (2005: 317), such swear words (as well as some other non-propositional uses of language) might represent fossilized clues to the evolutionary origins of human communication, given that their processing involves the right hemisphere, basal ganglia, thalamus and limbic structures. Basal-limbic structures are phylogentically old and the aspects of human communication associated with them are considered to be ancient, too (e.g. Van Lancker \& Cummings 1999, Bradshaw 2001). ${ }^{11}$

The possibility that sexual selection played a role in evolving syntax is also consistent with the findings reported in e.g. Ullman (2008) (see also

11 Note also that Tourette's Syndrome, a disorder caused by basal ganglia-limbic connection dysfunction, is characterized by involuntary production of obscene speech. 
Pinker \& Ullman 2002), that there is a gender difference when it comes to relying on declarative vs. procedural memory in language processing. Even though the two memories interact and can compensate to some extent for each other's weaknesses, declarative memory is primarily used for learning and processing of facts and events, and is modulated by estrogen. In language, it is responsible for the Lexicon, for simple words, but also for irregular morphological distinctions (dig-dug). On the other hand, procedural memory specializes for learning and control of cognitive and motor skills, as well as for sequences and rules. It is implicated in the left frontal-basal ganglia circuits and is modulated by dopamine. In language, it is responsible for rule-governed hierarchical and sequential composition (and decomposition) of complex forms, for syntax and regular morphology (walk-ed).

Ullman (2008) reports that males show frequency effects for irregular past tenses, but not for regular morphology, suggesting that males do not use declarative memory to store regulars, but rather rely on the procedural memory, the one that supports syntax. Females show frequency effects for both regulars and irregulars, suggesting that females use declarative memory to store even regulars. Such a gender difference in the processing of syntax may suggest that sexual selection played some role in the evolution of syntax. Future research on VN compounds may provide important insights into this matter, given that these compounds straddle the boundary between lexicon and syntax.

\section{Conclusion}

My conclusion is that the grammar behind VN compounds is the best candidate for a living fossil of proto-syntax. Little about these compounds makes sense except in the light of evolution. Their rudimentary flat combinatorial strategy, defying the most fundamental principles of modern morpho-syntax (e.g. headedness) is accompanied by the semantics and use that point to ritual insult and sexual selection, specializing for derogatory reference. Adding to the exotic nature of $\mathrm{VN}$ compounds, their verb surfaces in a(n) (proto-) imperative form. If $\mathrm{VN}$ compounds started to be coined in the ancient oneword stage of human language, a stage characterized by the use of imperative verb forms, it is to be expected that they would have been tinkered from what was already available, the imperative forms. These crude compounds, typically exhibiting the most basic of vocabulary, can nonetheless express abstract (human) traits not only with astounding succinctness, but also with humor and playfulness. Using this kind of compounding strategy at the dawn 
of language would have not only augmented the expressive power of human language enormously, but it would have also provided a foundation for future vocabulary and structure building.

\section{References}

Abrahams, R. D. (1962). Playing the dozens. Journal of American Folklore, 73, 209-220.

Adams, E. L. (1913). Word-Formation in Provençal. New York: Macmillan.

Andrě̌čin, L. (1955). Български език. Sofia.

Apte, M. L. (1985). Humor and laughter: An anthropological approach. Ithaca, NY: Cornell University Press.

Baker, M. (1996). The Polysynthesis Parameter. Oxford: Oxford University Press.

Bar-Shalom, E. \& Snyder, W. (1999). On the relationship between root infinitives and imperatives in early child Russian. In A. Greenhill et al. (Eds.), Proceedings of the $23^{\text {rd }}$ Annual Boston University Conference on Language Development. Somerville, Massachusetts: Cascadilla Press.

Becker, J. A. (1994). 'Sneak-shoes', 'sworders' and 'nose-beards': A case study of lexical innovation. First Language, 14, 195-211.

Belić, A. (1949). Savremeni srpskohrvatski književni jezik II. Nauka o gradjenju reči. Beograd: Naučna Knjiga.

Belić, A. (1960). Istorija srpskohrvatskog jezika. Knjiga II, Sveska 2: Reči sa konjugacijom. Beograd: Naučna knjiga.

Bickerton, D. (1990). Language and Species. Chicago: University of Chicago Press.

Bickerton, D. (1998). Catastrophic evolution: The case for a single step from protolanguage to full human language. In J. R. Hurford, M. Studdert Kennedy \& C. Knight (Eds.), Approaches to the Evolution of Language: Social and Cognitive Bases (pp. 341-358). Cambridge: Cambridge University Press.

Bolufer, J. A. (1920). Tratado de la formación de palabras en la lengua castellana. Madrid: Libería General de Victoriano Suárez. Preciados, núm. 48.

Bradshaw, J. L. (2001). Developmental Disorders of the Frontostratial system. Hove: Psychology Press.

Chomsky, N. (1995). The Minimalist Program. Cambridge, MA: MIT Press.

Clark, E., Hecht, B., \& Mulford, R. (1986). Coining complex compounds in English: Affixes and word order in acquisition. Linguistics, 24, 7-29.

Code, C. (2005). First in, last out? The evolution of aphasic lexical speech automatisms to agrammatism and the evolution of human communication. Interaction Studies, 6(2), 311-334.

Darmesteter, A. (1894). Traité de la formation des mots composés dans la langue française comparée aux autres langues romanes et au latin. Paris: Émile Bouillon. 
Darmesteter, A. (1934). A Historical French Grammar. English edition by Alphonse Hartog. First Edition in 1899. London: Macmillan \& Co.

Darwin, C. (1872). The Expression of the Emotions in Man and Animals. London: John Murray.

Darwin, C. M. A. (1874). The Descent of Man, and Selection in Relation to Sex. New edition, revised and augmented. New York: Hurst \& Company.

Delgado, R. A. (2006). Sexual selection in the loud calls of male primates: Signal content and function. International Journal of Primatology, 27, 5-25.

Dixon, R.M.W. (1994). Ergativity. Cambridge Studies in Linguistics 69. Cambridge: Cambridge University Press.

Downing, P. A. (1977). On the creation and use of English compound nouns. Language, 53(4), 810-842.

Fabb, N. (1984). Syntactic Affixation. Ph.D. Dissertation, MIT, Cambridge, MA.

Ferrari, F. (2005). A syntactic analysis of the nominal systems of Italian and Luganda: How nouns can be formed in the syntax. Ph.D. Dissertation, New York University.

Fischer, J., Kitchen, D. M., Seyfarth, R. M., \& Cheney, D. L. (2004). Baboon loud calls advertise male quality: Acoustic features and their relation to rank, age, and exhaustion. Behavioral Ecology and Sociobiology, 56, 140-148.

Fu, J., Roeper, T. \& Borer, H. (2001). The VP within nominalizations: Evidence from adverbs and the VP anaphor do-so. Natural Language and Linguistic Theory, 3, 549-582.

Garrioch, D. (1987). Verbal insults in eighteenth-century Paris. In P. Burke \& R. Porter (Eds.), The Social History of Language. Cambridge: Cambridge University Press.

Gil, D. (2005). Isolating-Monocategorial-Associational Language. In H. Cohen \& C. Lefebvre (Eds.), Handbook of Categorizaton in Cognitive Science (pp. 347-379). Amsterdam: Elsevier.

Hall, R. A. Jr. (1948). Descriptive Italian Grammar. Cornell Romance Studies: Volume II. Ithaca, New York: Cornell University Press and Linguistic Society of America.

Hurford, J. R., Studdert-Kennedy, M, \& Knight, C. (Eds.). (1998). Approaches to the Evolution of Language: Social and Cognitive Bases. Cambridge: Cambridge University Press.

Jackendoff, R. (1999). Possible stages in the evolution of the language capacity. Trends in Cognitive Sciences, 3(7), 272-279.

Jackendoff, R. (2002). Foundations of Language: Brain, Meaning, Grammar, Evolution. Oxford: Oxford University Press.

Jay, T. (1980). Sex roles and dirty word usage: A review of the literature and a reply to Haas. Psychological Bulletin, 88, 614-621.

Jespersen, O. (1954). A Modern English Grammar. Part III: Syntax. London: Allen \& Unwin.

Kempson, R. M. (1977). Semantic Theory. Cambridge Textbooks in Linguistics. Cambridge: Cambridge University Press. 
Kerns, J. A. \& Schwartz, B. (1972). A Sketch of the Indo-European Finite Verb. Leiden: E. J. Brill.

Kitchen, D. M., Seyfarth, R. M., Fischer, J., \& Cheney, D. L. (2004). Loud calls as indicators of dominance in male baboons (Papio cynocephalus ursinus). Behavioral Ecology and Sociobiology, 53, 374-384.

Klemensiewicz, Z., Lehr-Spławiński, T. \& Urbański, S. (1964). Gramatyka historyczna języka polskiego. Warszawa: Państwowe Wydawnictwo Naukowe.

Koneski, B. (1954). Gramatika na makedonskiot literaturen jezik, del. II. Skopje.

Kuryłowicz, J. (1964). The Inflectional Categories of Indo-European. Heidelberg: Carl Winter Unversitätsverlag.

Lees, R. B. (1960). The Grammar of English Nominalizations. The Hague: Mouton.

Lieber, R. (1992). Deconstructing Morphology: Word Formation in Syntactic Theory. Chicago \& London: The University of Chicago Press.

Lloyd, P. M. (1968). Verb-Complement Compounds in Spanish. Beihefte zur Zeitschrift für romanische Philologie. 116. Heft. Tübingen: Max Niemeyer Verlag.

Locke, J. L. (2009). Evolutionary developmental linguistics: Naturalization of the faculty of language. Language Sciences, 31, 33-59.

Locke, J. L., \& Bogin, B. (2006). Language and life history: A new perspective on the evolution and development of linguistic communication. Behavioral and Brain Science, 29, 259-325.

Marchand, H. (1969). The Categories and Types of Present-Day English WordFormation: A Synchronic-Diachronic Approach. Second, completely revised and enlarged edition. München: C. H. Beck'sche Verlagsbuchhandlung.

Maretić, T. (1899). Gramatika i stilistika hrvatskoga ili srpskoga jezika. Zagreb: L. Hartman.

Marsh, P. (1978). Aggro: The illusion of violence. London: Dent.

Meyer-Lübke, W. (1895). Grammaire des Langues Romanes. Tome II. Reprinted in 1923, New York/Paris: G.E. Stechert \& Co.

Mihajlović, V. (1992). Ime po zapovesti: Imperativni Onomastikon srpskohrvatskog jezika. [Name by Command]. Belgrade: Nolit.

Miller, D.G. (1975). Indo-European: VSO, SOV, SVO or all three? Lingua, 37, 3152.

Miller, G. (2000). The Mating Mind: How Sexual Choice Shaped the Evolution of Human Nature. New York: Doubleday.

Mirowicz, A. (1946). Wartość uczuciowa rozkaźnika a złożenia typu czyścibut. Język polski XXV. W Krakowie.

Murray, S. (2004). Truckdriver and Scarecrow Compounds in English and Spanish: A Unified Approach. MA Essay, Wayne State University, Detroit.

Parks, W. (1990). Verbal Dueling in Heroic Narrative: The Homeric \& Old English Traditions. Princeton, NJ: Princeton University Press.

Pinker, S. \& Bloom, P. (1990). Natural language and natural selection. Behavioral and Brain Sciences, 13, 707-784. 
Pinker, S. \& Ullman, M. T. (2002). The past-tense debate: The past and future of the past tense. Trends in Cognitive Sciences, 6(11), 456-463.

Prati, A. (1931). Composti imperativi quali casati e soprannomi. RLiR VII.

Progovac, L. (2005). Synthetic agent compounds in Serbian: An incorporation analysis. In M. Tasseva-Kurktchieva, S. Franks \& F. Gladney (Eds.), Formal Approaches to Slavic Linguistics 13: The Columbia Meeting 2004 (pp. 253264). Ann Arbor: Michigan Slavic Publications.

Progovac, L. (2006). Fossilized imperative in compounds and other expressions. Online Proceedings of the First Inaugural Meeting of SLS (Slavic Linguistics Society). Bloomington, In http://www.indiana.edu/ sls2006/page6/page6. html«

Progovac, L. (2008). What use is half a clause? In A. D. M. Smith, K. Smith \& R. Ferrer i Cancho (Eds.), Evolution of Language: Proceedings of the $7^{\text {th }}$ International EVOLANG Conference, Barcelona, Spain, 12-15 March 2008 (pp. 259-266). New Jersey: World Scientific.

Progovac, L. (2010). Imperative in compounds: Implications for historical and evolutionary studies. In P. Karlík (Ed.), Development of Language through the Lens of Formal Linguistics (pp. 137-145). Munich: Lincom Europe.

Progovac, L. \& Locke, J. L. (2009). The urge to merge: Ritual insult and the evolution of syntax. Special Issue of Biolinguistics, 3(2-3), 337-354.

Ridley, M. (1993). Evolution. Oxford: Blackwell Scientific Publications.

Roeper, T. (1999). Leftward Movement in Morphology. MIT Working Papers in Linguistics, 34, 35-66.

Roeper, T. \& Siegel, D. (1978). A Lexical Transformation for Verbal Compounds. Linguistic Inquiry, 9, 199-260.

Rohrer, C. (1977). Die Wordzusammensetzung in Modernen Französisch. Tübingen: TBL Verlag Gunter Narr.

Rolfe, L. (1996). Theoretical stages in the prehistory of grammar. In A. Lock \& C. R. Peters (Eds.), Handbook of Human Symbolic Evolution (pp. 776-792). Oxford: Clarendon Press.

Selkirk, E. O. (1982). The Syntax of Words. Cambridge, MA: MIT Press.

Speijer, J. S. 1886. Sanskrit Syntax. Delhi: Jayyad Press.

Spencer, A. (1991). Morphological Theory. Oxford: Basil Blackwell.

Sproat, R. (1985). On Deriving the Lexicon. Ph.D. Dissertation, MIT, Cambridge, MA.

Stevanović, M. (1956). Imperativne složenice [Imperative Compounds]. Naš Jezik, Nova Serija, VIII (1-2), 6-18.

Stevanović, M. (1966). Gramaticka srpskohrvatskog jezika. Cetinje: Obod.

Studdert-Kennedy, M. (1991). Language development from an evolutionary perspective. In N. A. Krasnegor, D. M. Rumbaugh, R. L. Scheiefelbusch \& M. Studdert-Kennedy (Eds.), Biological and Behavioral Determinants of Language Development (pp. 5-28). Hillsdale, NJ: Erlbaum. 
Tchekhoff, C. (1979). From Ergative to Accusative in Tongan: An example of synchronic dynamics. In F. Plank (Ed.), Ergativity: Towards a Theory of Grammatical Relations (pp. 407-418). London: Academic Press.

Ułaszyn, H. (1923). Gramatyka języka polskiego. Polska Akademia Umiejętności w Krakowie: Słowotwórstwo.

Ullman, M. T. (2008). Variability and redundancy in the neurocognition of language. Paper presented at the Workshop on Human Universals in Bamberg, Germany.

Van Lancker, D. \& Cummings, J. L. (1999). Expletives: Neurolinguistic and neurobehavioral perspectives on swearing. Brain Research Reviews, 31, 83104.

Weekley, E. (1916). Surnames. New York: E.P. Dutton \& Co.

Weekley, E. (1927). More Words Ancient and Modern. New York: E.P. Dutton and Company.

Williams, E. (1981). On the notions "Lexically related" and "Head of a word." Linguistic Inquiry, 2, 245-274.

Yonge, C. (1863). History of Christian Names. London: Parker, Son, and Bourn, West Strand.

Živanović, J. (1904). Složene reči u srpskom jeziku. Glas Srpske Akademije Nauka / Glas Srpske Kraljevske Akademije LXVIII, 175-207. Drugi Razred 42. Belgrade: Državna Štamparija. 